$12-1-2020$

\title{
Colorado--The Changing Landscape of Land Use Law and Regulations Impacting the Colorado Oil and Gas Industry: From the Colorado Oil and Gas Conservation Act of 1951 to Senate Bill
} 181 of 2019

Ralph A. Cantafio

Ralph@fncmlaw.com

Follow this and additional works at: https://scholarship.law.tamu.edu/journal-of-property-law

Part of the Property Law and Real Estate Commons

Recommended Citation

Ralph A. Cantafio, Esq., Colorado--The Changing Landscape of Land Use Law and Regulations Impacting the Colorado Oil and Gas Industry: From the Colorado Oil and Gas Conservation Act of 1951 to Senate Bill 181 of 2019, 6 Tex. A\&M J. Prop. J. 31 (2020).

This Student Article is brought to you for free and open access by Texas A\&M Law Scholarship. It has been accepted for inclusion in Texas A\&M Journal of Property Law by an authorized editor of Texas A\&M Law Scholarship. For more information, please contact aretteen@law.tamu.edu. 


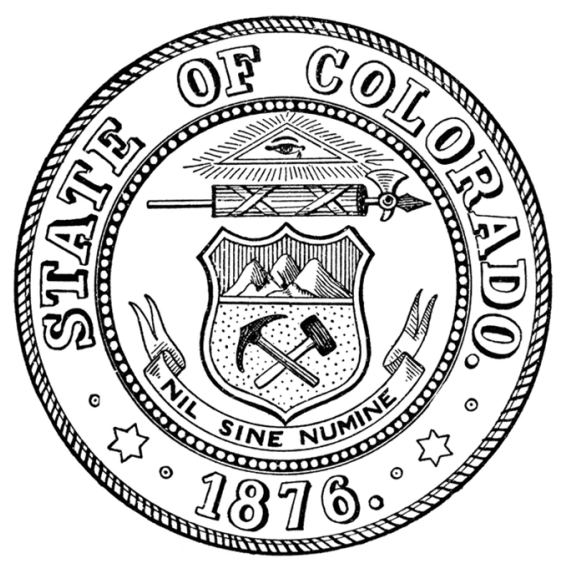

Colorado

The Changing Landscape of Land Use LAW AND

Regulations ImPaCTING THE COLORAdo OIL AND GaS

INDUSTRY: FROM THE COLORADO OIL AND GAS CONSERVATION ACT OF 1951 to SenAte BILl 181 OF 2019

\author{
Ralph A. Cantafio, Esq. ${ }^{1}$
}

When Colorado Democratic Governor Jared Polis approved Senate Bill 181, this new law significantly redirected the historical focus of Colorado oil and gas regulation. ${ }^{2}$ This provided a significant

DOI: https://doi.org/10.37419/JPL.V6.I3.5

1. Ralph A. Cantafio is Managing Partner of Feldmann Nagel Cantafio PLLC with offices located in Cheyenne, WY, as well as Boulder, Denver and Steamboat Springs, $\mathrm{CO}$. He is also a lecturer at the University of Colorado Denver in the Global Energy Management Program where he teaches graduate students Environmental Regulatory, Legal and Political Environment of the Energy Industry and Energy Law: Property, Contracts and Transaction. His law practice focuses on transactional work and litigation in the Oil and Gas Industry, where he also acts as a Mediator and Arbitrator. Mr. Cantafio is licensed in, among other states, Alaska, Colorado, North Dakota, Pennsylvania, Texas, Wyoming and Utah.

2. Dale Ratliff, Senate Bill 19-181: Colorado enacts first-of-its 
delegation of land use related authority to local government for the first time since the passage of this Act in 1951. This new law moved away from the traditional notion of statewide regulation based upon exclusive jurisdiction by the Colorado Oil and Gas Conservation Commission ("COGCC"). While this change of legislative focus is significant, this latest direction is probably a natural continuation of a general trend that has been emerging in Colorado since certain Supreme Court Opinions were announced in 1992, as explained later in this Article. As the State of Colorado has, among other things, grown in population, residential housing now significantly finds itself competing with oil and gas development in the same geographical areas, especially the suburbs of the "Front Range." Simultaneously, the political sentiment of Colorado has trended into a more significantly Democratic direction from a historically Republican majority. The law as to the governance of the oil and gas industry has now changed as a result of the passing of SB 181 - from fostering the development of oil and gas industry to a new paradigm requiring the weighing of interests, including environmental concerns. This Article provides a historic explanation to allow the reader to better understand how this transition has come about. That which is observed in Colorado might also be seen as a potential harbinger of future change that could be noted in other oil and gas states.

\section{THE ACT}

The Colorado Oil and Gas Conservation Act ("The Act") was enacted in $1951 .^{3}$ It sought to address a host of objectives. Part of the legislative objective in passing this Act was to provide a single and monolithic set of laws that would apply to the development of a statewide oil and gas industry. While no single statement could summarize the multitude of sentiments of the entirety of the Colorado legislature in passing this law (as is the case with virtually every piece of legislation), creating a state-wide system for the permitting,

kind oil and gas legislation, A.B.A. (Oct. 25, 2019) https://www.americanbar.org/groups/environment_energy resources/publications/trends/2019-2020/november-december2019/senate-bill/ [https://perma.cc/PW94-HMRZ].

3. 1951 Colo. Sess. Laws 651, 662 (repealing CoLO. STAT. ch. 118, $\S \S 39,40,41,42,43,44,49,50,52,64,65,66$, and $67(1935))$ (codified at COLO. REV. STAT. \$34-60-101) (1951). 
licensing, and regulation of the oil and gas industry made sense from the point of view of promoting its prosperity. So, too, was the reality that the Act recognized that individual cities or most counties did not have either the local budget or the available expertise to meaningfully provide regulation of what is an admittedly complex and technical industry. It is also important to recall that near the time that the Act was passed, the total population of Colorado was $1,325,089 .{ }^{4}$ By 2015 , the population of Colorado had grown to $5,456,571 .^{5}$ It is important to keep in mind the vast changes Colorado has experienced in the last sixty-five plus years. Infrastructure that is taken for granted today, such as Interstate-25 or Interstate-70, did not exist some sixty-five years ago (although there was a statewide road system). ${ }^{6}$

Until perhaps the 1980 s, much oil and gas development occurred in relatively unimproved geographical areas that were sparsely populated, occurring primarily nearby agricultural communities. ${ }^{7}$ With the ever-growing population growth of the Colorado "Front Range" (which generally is defined as Ft. Collins to the north and Pueblo to the south along the I-25 corridor) land use issues and issues resulting from an encroaching population intersecting with that of the oil and gas industry became inevitable. Nonetheless, the general legal framework pertaining to the regulation of oil and gas industry was one focused on stateside regulation through approximately 1992 .

\section{The 1992 Colorado Supreme Court DeCISIONS}

On June 8, 1992, the Colorado Supreme Court announced two opinions that significantly changed the legal landscape of oil and gas regulation in Colorado: (1) The Board of County Commissioners, of

4. U.S. Dep't Commerce, No. 4, 1950 Census of Population PRELIMINARY REPORTS (1950).

5. Colorado's 2016 Population \& Economic Overview, COLO. STATE DEMOGRAPHY OFF. (Feb. 7, 2017) https://demography.dola.colorado.gov/crosstabs/2016-overview/ [https://perma.cc/ŻEY-MNRN].

6. Fun Facts, COLO. DEP'T TRANSP., https://www.codot.gov/about/CDOTHistory/50th-anniversary/funfacts.html [https://perma.cc/2A4Z-JENR] (last visited Nov. 7, 2019).

7. See Kathryn M. Mutz, Home Rule City Regulation of Oil and Gas Development, 23 COLO. L. 2771, 2771 (1994). 
La Plata County vs. Bowen/Edwards Associates, Inc. ${ }^{8}$ and (2) Voss vs. Lundvall Brothers, Inc. ${ }^{9}$ Justice Joseph Quinn authored each opinion. As you will read, traditional notions of preemption by the COGCC were reconsidered. ${ }^{10}$

The more straightforward case is Voss. Here, the City of Greeley enacted a land use ordinance that imposed a complete ban on the drilling of any oil, gas, or hydrocarbon wells within the city limits. ${ }^{11}$ The Greeley City Counsel enacted Greeley Ordinance 90 prohibiting any drilling for oil and gas within city limits. ${ }^{12}$ An issue raised included whether or not this Ordinance violated Article V, Section 35 of the Colorado Constitution. ${ }^{13}$ The Plaintiffs, Lundvall Brothers, filed their lawsuit seeking Declaratory Relief. They asked the court to declare the Greeley Ordinance as null and void in violation of the Act. ${ }^{14}$

The District Court of Weld County found that the Greeley Ordinance was facially void because "the entire area of oil and gas exploration and regulation, including location of sites within municipalities [has] been preempted by the State of Colorado" and "[has been] delegated to the Oil and Gas Conservation Committee Commission." 15

This order by that District Court was in substantial concurrence with the traditional notions of preemption Colorado courts had enforced since this Act became law. However, and as discussed below, the sister opinion of Bowen/Edwards, as relied upon in Voss, now directed Colorado oil and gas regulatory law into a new, more collaborative direction. Justice Quinn noted:

The Oil and Gas Conservation Act, [cite omitted] does not totally preempt a county from exercising its land use authority over any and all aspects of oil and

\footnotetext{
8. 830 P.2d 1045 (Colo. 1992)

9. 830 P.2d 1061 (Colo. 1992)

10. See Bowen/Edwards Assocs., 830 P.2d at 1056-57; Voss, 830 P.2d at 1069 .

11. Voss, 830 P.2d at 1063.

12. $I d$.

13. Id. at 1069 .

14. Id. at 1063 .

15. Id. (quoting Lundvall Bros., Inc. v. Voss, 812 P.2d 693 (Colo. App. 1990)).
} 
gas development operations in unincorporated areas of the county. In the instant case we must determine whether the scope of Greeley's authority as a homerule city to delegate land use within its municipal borders extends to a total ban on the drilling of an oil, gas, or hydro carbon well within its city limits. ${ }^{16}$

Citing the sister Bowen/Edwards opinion, Justice Quinn further noted in Voss:

in addition to issuing permits for oil and gas drilling operations, the Commission is authorized to regulate the drilling, production, and plugging of wells, the shooting and chemical treatment of wells, the spacing of wells, and the disposal of set water and oil field wastes [cite omitted] as well as to limit production for any pool or field for the prevention of waste and allocate production from pool or field among or between tracts of land having separate ownership on a fair and equitable basis so that each tract will produce no more than its fair share ${ }^{17}$

Ultimately, Justice Quinn determined that the Greeley Ordinance violated basic conscripts of the Act:

We conclude that the state's interests in efficient oil and gas development and production throughout the state, as manifested in the Oil and Gas Conservation Act, is sufficiently dominant to override a home-rule cities in position of a total ban on the drilling of any oil, gas, or hydro carbon wells within the city limits. In so holding, we do not mean to imply that Greeley is prohibited from exercising a land-use authority over those areas of the city in which oil and gas activities are occurring or are contemplated."18

16. Id. at 1064 (emphasis added).

17. Id. at 1065 .

18. Id. at 1068 . 
Bowen/Edwards focused on a different issue: whether or not the Act preempted La Plata County's authority to enact land-use regulation that, as a by-product, limited oil and gas operations within that county. ${ }^{19}$ Up until the announcement of this case, the understanding had been that a declared purpose of the Act was to preempt county intervention, even when such county regulation incidentally impacted the oil and gas industry. ${ }^{20}$ Justice Quinn seized upon the 1985 Amendments to the Act which spoke to the growing overlap of the oil and gas industry into more densely populated areas. ${ }^{21}$ Based upon those Amendments, the COGCC was found to possess authority to "promulgate rules and regulations to protect the health, safety, and welfare of the general public and the drilling completion, and operation of oil and gas wells in production facilities." 22 La Plata County passed a set of land-use regulations, which contained the following Statement of Purpose:

these regulations are enacted to protect and promote the health, safety, morals, convenience, order, prosperity or general welfare of the present and future residences of La Plata County. It is the counties intent by enacting these regulations to facilitate the development of oil and gas resources within the unincorporated area of $\mathrm{La}$ Plata County while mitigating potential land use conflicts between such development and existing, as well as planned, land uses. ${ }^{23}$

Justice Quinn observed that three fundamental grounds existed upon which a Colorado state statute could preempt a county ordinance or regulation: (1) the express language of the statute indicated the state may preempt local authority over the subject matter in question; (2) preemption could be inferred if the state statute impliedly evinces a legislative intent to completely occupy a given field; or (3) a local law may be partially preempted where its operational effect would

19. Bd. of Cty. Comm'rs v. Bowen/Edwards Assocs., Inc., 830 P.2d 1045, 1057 (Colo. 1992).

20. Id.

21. Id. at 1049 .

22. Id. (citing COLO. REV. STAT. § 34-60-106(11) (1991)).

23. Id. at 1050 (citing La Plata County Regulation $\S 6.103$ ).. 
conflict with application of the state statute. ${ }^{24}$ The Colorado Supreme Court ultimately remanded the matter for the taking of further evidence instructing:

on the basis of the limited record before us, we are unable to determine whether an operational conflict exists between La Plata County's oil and gas regulations and the Oil and Gas Conservation Act. The purpose of the county regulations is to 'facilitate the development of oil and gas resources within the unincorporated area of La Plata County while mitigating potential land use conflicts we have seen between such development existing, as well as planned, land uses' [cite omitted] this statement of purpose evinces an obvious intent to regulate in a manner that does not hinder the achievement of the State's interests in fostering the efficient development, production, and utilization of oil and gas resources in the state [cite omitted $]^{25}$

Justice Quinn:

The County's regulations also appear to be designed to harmonize oil and gas development and operational activities with the state's overall plan for land use and with the state's interest in those development and operational activities ${ }^{26}$

Bowen/Edwards as a result created a legal environment where some twenty-five years of litigation ensured typical harkening upon the application of the terms "operational effect" and "operational conflict."

III.AMENDMENT 74 AND PROPOSITION 112

24. Id. at 1056-57.

25. Id. at 1059-60.

26. Id. at 1060 . 
By November 2018, despite a multitude of litigations, the issue as to the local regulation of land use impacting the oil and gas industry has migrated from the judicial branch of government to that of the ballot box. ${ }^{27}$ Colorado voters were faced with a decision as to Amendment 74 and Proposition 112. Proposition 112 was an initiative that would have increased oil and gas drilling setbacks, globally speaking, distancing oil wells from homes, businesses, and waterways. $^{28}$ This Proposal included a 500-foot setback from homes and a 1000-foot setback from schools. New oil and gas developments would also have been subject to a 2,500-foot setback. ${ }^{29}$

On the same ballot, Amendment 74, if passed, would have permitted property owners to seek compensation from government entities any time a government action or regulation devalued their property. ${ }^{30}$ Additionally, the Amendment would have allowed private homeowners to seek judicial intervention and, under appropriate circumstances, compensation for takings type claims based on a government action or regulation that devalued property. ${ }^{31}$

Under Amendment 74, a government regulation or government permit and/or license that is part and parcel with oil and gas development could have been characterized as an act that would subject the government to liability for essentially a taking. ${ }^{32}$

Proposition 112 was ultimately defeated by approximately $57 \%$ to $43 \%{ }^{33}$ Amendment 74 was simultaneously defeated by approximately $54 \%$ to $46 \% .{ }^{34}$ Although defeated, each demonstrated a very strong sentiment held by certain segments of the Colorado voting population that the then current regulations pertaining to the development of oil and gas was perceived as inadequate.

27. Legis. Council of the Colo. Gen. Assemb., 2018 State BALLOT INFORMATION BOOKLET, NO. 702-2 (2018).

28. Id. at 82 .

29. Id.

30. Id. at 52 .

31. Id.

32. John Aguilar, Prop 112 Fails as Voters Say No to Setbacks for Oil and Gas, THE DENVER POST (NOV. 6, 2018, 7:13 PM), https://www.denverpost.com/2018/11/06/colorado-proposition-112results/ [https://perma.cc/B2MJ-8AZX].

33. Id.

34. Id. (noting that the Amending of the Colorado Constitution now requires approval by a super majority of $55 \%$ to become law). 


\section{MARTINEZ}

In January 2019, the Colorado Supreme Court decided Martinez v. Colorado Oil \& Gas Commission. ${ }^{35}$ The Plaintiffs here were self-described youth activists. They dedicated substantial effort towards pursuing their objective of protecting the health of Colorado citizens and its environment. ${ }^{36}$ These Plaintiffs proposed to the COGCC a rule that would have, among other things, prohibited the COGCC from issuing any permits for the drilling of oil and gas wells "unless the best available science demonstrates, and an independent third party confirms, the drilling can occur in a manner that does not cumulatively, with other actions, impair Colorado's atmosphere, water, wildlife, and land resources, does not adversely impact human health, and does not contribute to climate change."37 The COGCC in response to this proposed rule solicited and received public comment. It thereafter declined to engage in rulemaking to further consider the proposed rule because:

(1) the rule would have required the commission to readjust the balance purportedly crafted by the General Assembly under the Act and condition new oil and gas drilling on a finding of no cumulative adverse impacts, both of which the Commission believed to be beyond its statutory authority, and (2) the Commission was already working with the Colorado Department of Public Health and Environment ("CDPHE")" to address the concerns to which the Rule was directed and other Commission priorities took precedence over the proposed rule making at the time. ${ }^{38}$

The case at hand is interesting. The Colorado Court of Appeals disagreed with the District Court. The Colorado Court of Appeals found in favor of the Plaintiffs. ${ }^{39}$ The Court of Appeals found that the COGCC and the District Court erred in determining the scope of the

35. 433 P.3d 22 (Colo. 2019).

36. $I d$. at 24 .

37. Id. at 25 .

38. $I d$.

39. See id. 
authority of the COGCC under the Act. It decided the COGCC was responsible for "fostering balanced, non-wasteful development [that] is completed subject to the protection of healthy safety and welfare." $" 40$

The Colorado Supreme Court ultimately reversed:

First our review of an administrative agency's decision is to whether to engage in law making is limited and highly deferential. Second, in our view, the Commission correctly determined that, under the applicable language of the Act it could not properly adopt the rule proposed by respondents. Specifically, as the Commission recognized, the pertinent provisions do not allow it to condition all new oil and gas development on a finding of no cumulative adverse impacts to public health and environment. Rather, the provisions make clear that the commission is required to (1) to foster the development of oil and gas resources, protecting and enforcing the rights of owners and producers; and (2) in doing so, to prevent and mitigate significant adverse environmental impacts to the extent necessary to protect public health, safety and welfare, but only after taking into consideration cost effectiveness and technical feasibility ${ }^{41}$

Out of the substance of this opinion, it is this "fostering" of the development of oil and gas resources as an objective of the Act that would be rejected by Senate Bill 181. ${ }^{42}$

The Colorado Supreme Court found:

these provisions do not allow the Commission to condition all new oil and gas development on a finding of no cumulative adverse impacts to public health and the environment, as Respondents assert the commission must do. Nor do we perceive the statutory language as creating a balancing test by which the publics interests in oil and gas development is weighed

40. Id. at 24 .

41. Id. at 25 .

42. S.B. 9-181, 72nd Gen. Assemb., 1st Reg. Sess. (Colo. 2019). 
against its interest in public health and the environment, as Petitioners seem to suggest. Rather, in our view, the pertinent provisions make clear the commission is required (1) to foster the development of oil and gas resources, protecting and enforcing the rights of owners and producers, and to in doing so, to prevent and mitigate significant adverse environmental impacts to the extent necessary to protect public health, safety, and welfare, but only after taking into consideration cost effectiveness and technical feasibility $^{43}$

\section{SuMmary OF THE StATE OF THE REgULATION OF OIL AND GAS/PRE-2019 LEGISLATIVE SESSION}

Post Martinez, a summary of Colorado law pertaining to the regulation of the oil and gas industry was the COGCC was charged with "fostering" the responsible and balanced development, production, and utilization of oil and gas in a manner consistent with the protection of public health, safety, and welfare, including protection of the environment and wildlife resources. ${ }^{44}$ The COGCC was further responsible for protecting public and private interests in oil and gas against waste. ${ }^{45}$ The COGCC was afforded broad latitude to carry out its statutory mandate under circumstances where the COGCC adopted rules that governed the operational aspects of oil and gas operations to implement this as authority. ${ }^{46}$ Applying Voss and Bowen/Edwards, a home-rule entity in implementing land use regulation first must apply the same only within its physical jurisdiction. ${ }^{47}$ Recall, oil and gas reservoirs do not always neatly conform to man-made boundaries. Next, so long as such regulation does not frustrate development of and at the same time could be harmonized with the development of oil and gas in a manner consistent

43. Martinez, 433 P.3d at 41

44. COLO. REV. STAT. § 34-60-102(I) (2019).

45. \$ 34-60-102(II).

46. COLO. REV. STAT. § $\$ 34-60-105$ to 34-60-106 (2019).

47. Voss v. Lundvall, Inc., 830 P.2d 1061, 1068 (Colo. 1992); Bd.

of Cty. Comm'rs v. Bowen/Edward Assocs., Inc., 830 P.2d 1045, 1056 (Colo. 1992). 
with the stated goals of the Act, home-rule regulation would be given effect.

\section{SENATE BILL 181}

With the election of Democratic Governor Jared Polis in November 2018, and the Colorado Senate and House of Representatives now controlled by a Democratic majority, the temperament and objectives as to historic regulation of the oil and gas industry in Colorado changed precipitously. ${ }^{48}$ Pre-Senate Bill 181, the Mission Statement of the Act was to:

foster the responsible, balanced, development and production and utilization of the natural resources of oil and gas in the state of Colorado in a manner consistent with protection of public health, safety and welfare, including protection of the environment and wildlife resources. ${ }^{49}$

After adoption of Senate Bill 181, the mandate of the COGCC significantly changed:

the commission shall regulate oil and gas operations in a reasonable manner to protect and minimize adverse impacts to public health, safety, and welfare, the environment, and wildlife resources and shall protect against adverse environmental impacts on any air, water soil, or biological resource resulting from oil and gas operations. ${ }^{50}$

\section{CurRent ImPlementations of SENATE Bill 181}

As of Fall 2019, the COGCC is engaged in implementing Senate Bill 181 and is in the midst of increasing protection of public health, safety, welfare, environment, and wildlife, while considering

48. § 34-60-102(1)(a).

49. Id. (emphasis added).

50. $\S 34-60-106(2.5)(a)$. 
these cumulative impacts on the oil and gas industry. ${ }^{51}$ The COGCC is currently enacting what it calls a "neutral" regulatory framework, as opposed to one that "fosters" the development of the oil and gas industry. ${ }^{52}$ COGCC is currently establishing a "holistic and contextual decision making process" with an objective, in part, of developing increased public trust in the COGCC. ${ }^{53}$ Most significantly, there is a significant restructuring of the very relationship between state and local government as to oil and gas regulation. ${ }^{54}$ The notion of preemption, first modified by Bowen/Edwards, has now been substantially abandoned.

Potential new rules and practices include:

1. Requiring emergency response plans and tactical response plans as conditions to permit filings.

2. Incorporating new environmental and safety protections to existing facilities.

3. Minimizing flaring and truck traffic.

4. Examining the efficacy of mechanical integrity testing (MITs).

5. Reforming spill reporting.

6. Evaluating best management practices in the context of multi-well horizontal developments.

7. Developing alternative site analysis in conjunction with local government regulation.

8. Creating basin-wide spacing.

9. Using cumulative impacts to evaluate and develop permit reviews and best managed practices.

10. Right sizing or re-examining the locating of well paths.

11. Examining cumulative impacts to better address noise, odor, and other nuisances.

51. COLO. REV. STAT. § 29-20-104(1)(h) (2019).

52. KeYstone CENTER, COLORADO OIL \& GAS TASK ForCe Final REPORT 3 (2015), https://www.colorado.gov/pacific/sites/default/files/atoms/files/2015, $\% 20$ Oil $\% 20$ Gas $\% 20$ Task $\% 20$ Force\%20Report.pdf [perma.cc/2L4DBA7C].

53. JEFF RobBins, Insights InTO COGCC RULEMAKING FROM 30,000', COLO. OIL \& GAS CONSERVATION COMM'N 19-22 (2019), https://cogcc.state.co.us/documents/sb19181/Overview/SB 19 181_ Rulemaking Update_20190821_rev.pdf [perma.cc/GU3U-4ZAJ].

54. Ratliff, supra n̄ote 2. 
12. Evaluating safety management protocols and addressing liability seeking compensation as to historic spills. ${ }^{55}$

Emphasizing the restructuring of the traditional state-local relationship, the most significant change is the incorporation of siting authority in the Act, especially in the permitting process. Previously, local regulation was restricted as set forth in Bowen/Edwards. ${ }^{56}$ There also exists a new emphasis on evaluating the appropriate parameters of drilling and spacing units. ${ }^{57}$

There will also be the incorporation of cumulative impacts into the COGCC permitting process, consistent with C.R.S. § 34-60106(11)(c)(II).

\section{The Future OF SENATE BILL 181}

The ultimate results of Senate Bill 181 are still not known. Those aligned against the oil and gas industry had hoped that Jeffery Robinson, the Director of the COGCC, would have as of Fall 2019 more significantly implemented Senate Bill 181. Aggressive antiindustry sentiment does not appear to be yet observed. As stated by Governor Polis at the time Senate Bill 181 was signed: "This is an important step for the stability of Colorado, to end the oil and gas wars in a way that everyone wins." 58

Consistent with Senate Bill 181, there have been identified sixteen "objective criteria" so as to guide the rule-making process. It has been represented that the sixteen "objective criteria" would maintain the status quo until new regulations enacting Senate Bill 181 could be approved. Since the passage of Senate Bill 181, over 450 wells have been drilled in Colorado. ${ }^{59}$ A total of 1,500 permits for oil and gas drilling have been approved since Governor Polis was sworn

55. S.B. 181, 72d Gen. Assemb., Reg. Sess. (Colo. 2019).

56. Bd. of Cty. Comm'rs v. Bowen/Edward Assocs., Inc., 830 P.2d 1045,1059 (Colo. 1992); see also COLO. REV. STAT. § 34-60-106(1)(f) (2019).

57. See Colo. Rev. Stat. AnN. § 34-60-116 (2019).

58. Phillip Doe, The Bad News about SB 181, BOULDER WKLY, (Aug. 29, 2019), https://www.boulderweekly.com/news/the-badnews-about-sb-181// [https://perma.cc/Y26W-NN6D].

59. Id. 
in. ${ }^{60}$ The drilling of new oil and gas wells has physically moved from more densely populated areas to areas of less population in many instances.

Controversial issues such as setbacks remain unresolved. Currently, Director Robins has enacted 1,500-foot setbacks, a distance short of the 2,500 feet suggested by Proposition 112. ${ }^{61}$ A different issue of concern has been the amount of financial assurance required of operators. Financial assurance and bonding are the financial vehicles to guarantee that Operators can pay the cost of protecting the public from wells not plugged and abandoned in compliance with state law. ${ }^{62}$ Traditionally, there have been complaints that bending and adequate assurance have been underfunded.

Ultimately, no one knows that end result of regulation to be enacted as a result of Senate Bill 181. The result of the inevitable litigation is even less known.

\section{FINAL COMMENT}

What does this evolution of oil and gas regulation in Colorado mean? It is very hard to say. In Colorado, the oil and gas industry creates over $\$ 600$ million in tax revenue annually. ${ }^{63}$ Much of this tax money funds public education. Furthermore, a cornerstone of the domestic economy of the United States, not to mention the global economy, is predicated upon readily available energy that can be purchased at an affordable price. The reality is that there currently exists no credible formula for providing adequate energy, either domestically or globally, in light of a growing population and growing demand for energy that does not significantly include oil and gas. As a result, there exists significant real-life parameters that require critical thinking. Clean energy alone based on current technology and the preservation of our economy without destroying local, state, domestic, and global economies cannot be reasonably anticipated to provide the

60. $I d$.

61. Id.

62. Id.

63. Oil and Gas Generates More than $\$ 600$ Million Per Year in Revenue for K-12 and Higher Education, COLO. PETROLEUM ASS'N (Jan. 29, 2019), http://www.coloradopetroleumassociation.org/reportoil-and-gas-generates-more-than-600-million-per-year-in-revenuefor-k-12-and-higher-education/ [https://perma.cc/TPC4-KJ96]. 
adequate supply of energy at a reasonable price. Oil and gas, not to mention coal, remain a significant part of supply so as to meet current and future energy demands. Solving the problem of climate change is the greatest challenge facing the energy industry and society in upcoming decades. The trick is how to provide plentiful and affordable energy that solves critical climate change issues in such a way that does not destroy domestic or global economies.

Ultimately, this shift in local regulation of the oil and gas industry should not be even remotely unexpected. As this Article began, a burgeoning Colorado population observed at the same time as a growing oil and gas industry resulted in a conflict between new populations that were inhabiting the same areas where the oil and gas industry was now drilling. Attempting to harmonize these concurrent uses and, more importantly, the inevitable conflict resulting from each increasingly occupying the same geographical area is a challenge. It is probably not enough to merely come to conclusions as to whether or not the historic regulation of the oil and gas industry was any better or worse than what can be expected in the future. Quite frankly, no system is perfect. As to what transpires in the future, no one can really say.

Nonetheless, the movement away from preemption observed in Colorado to one of local regulation is probably going to be repeated elsewhere. In states where one observes an increase in population along with a less tolerant acceptance of traditional oil and gas industry practices, regulation of the industry moving from state to local control is probably inevitable. Whether or not this change is of benefit in reconciling issues as to climate change and population development with that of energy availability and cost, that result probably is going to be dependent upon the wisdom of our local and statewide politicians. 